\title{
The Influence of Home Buyer Sentiment on Chinese Housing Prices_—_ Based on Media Text Mining
}

\author{
Qing Gao ${ }^{1} \&$ Tianxiao Zhao ${ }^{1}$ \\ ${ }^{1}$ School of Economics, Jinan University, Guangzhou, China \\ Correspondence: Qing Gao, School of Economics, Jinan University, Guangzhou, 510000, China. E-mail: \\ 554777985@qq.com
}

Received: July 26, 2018

Accepted: August 18, 2018

Online Published: August 30, 2018

doi:10.5539/ijef.v10n9p145

URL: https://doi.org/10.5539/ijef.v10n9p145

\begin{abstract}
In recent years, housing prices in major cities in China have generally maintained an upward trend, and housing prices have remained high for a long time. China's economic growth has its own particularity in the world, and the real estate market as a major support point for the economy, its future development is crucial to the economy. Taking Guangzhou as an example, this paper uses text mining method to extract media influence from media texts, and constructs the buyer confidence index, and uses it as a proxy variable for buyers' mental expectations. This article finally obtained a total of 115,139 articles on the housing market, forming an article pool for text mining. In the study and analysis of the explanatory effect of the home buyer confidence index on housing prices, this paper uses multiple linear regression to analyze the main factors affecting housing prices, and concludes that buyers' sentiment is significantly positively correlated with house prices.
\end{abstract}

Keywords: housing price, mental expectation, media influence, buyer confidence index

\section{Introduction}

\subsection{Research Background}

Since 1998, China's real estate industry has fully started market-oriented development. In 2003, the Chinese government clearly identified the real estate industry as a new economic growth point, and the real estate industry entered a rapid development channel. As a basic industry with high relevance, real estate plays a vital role in the sustained growth and development of the national economy. After the 2008 financial crisis, the "four trillion rescue" plan promoted by the Chinese government led to a surge in the credit, and financial institutions showed high leverage, while house prices rebounded rapidly. A series of problems such as the real estate bubble and the related land finance policy as well as the decline of the real economy have seriously affected the healthy development of the national economy and aroused widespread concern in society. At the same time, news media, which should deliver information to the public without partiality, is no longer satisfied with truthful reporting of social facts, its functions leaning towards commenting and predicting. Especially when the tentacles of the current network have extended to various fields of people's lives, the mass communication activities borrowing network technology are extremely active, and almost no one can get rid of the influence of media reports. Small investors, who are considered as sentiment traders in behavioral finance theory or noise traders, often base their investment decisions on the expectations of future price movements, and the media is undoubtedly the most convenient way that investors access to information. Most of the market information on which the expectations are based is derived from the media (Nofsinger, 2001; Fehle et al., 2003).

\subsection{Research Significance}

At present, most of the literature focuses on analyzing and predicting the trend of the real estate market from the perspective of supply and demand factors such as disposable income, mortgage interest rates, land costs, and other urban economics such as city size, traffic conditions, population aggregation, and public goods supply. However, traditional economic theory cannot fully explain the phenomenon of speculation, herding, noise trading, etc. in the real estate market. Therefore, many scholars have begun to pay attention to the psychology and behavior of micro-subjects in the market, focusing on consumer expectations in behavioral economics. Grasping the psychology and emotions of the trading entities in the real estate market is of great significance to truly understand the internal mechanism of real estate price and trading volume fluctuations and to explain the 
actual operating characteristics of real estate prices. If we can reasonably and accurately predict the changes in property prices and trading volume, it is not only easy for consumers to judge the housing market and formulate a housing purchase plan, but it can enable the government to limit the real estate price to a certain range while maintaining a moderate increase in trading volume. Stabilized market is essential to the healthy development of the overall national economy.

\subsection{Research Methods}

This paper uses the text mining and multiple linear regression methods used by Soo (2013) to analyze the sentiment and real estate prices of buyers in Guangzhou. When portraying investor sentiment, this article explores and quantifies media influence and uses it as a proxy variable for buyers' emotions. In explaining the influence of buyers' sentiment on housing prices, this paper uses multiple linear regression to analyze housing prices to determine the impact of buyers' sentiment on housing prices. In the test of the robustness of the model, this paper will introduce Beijing, Shanghai and Shenzhen for comparison.

\section{Literature review}

\subsection{News Media and Emotions}

Many groundbreaking literature on asset price bubbles imply or explicitly point out that journalism has a significant impact on sentiment, and corroborate the reliability of media tone as a proxy for investor sentiment (Wang et al., 2015). As we all know, the media plays an important role in the capital market, which is the medium for obtaining information, which in turn affects asset pricing. You et al. (2012) used the long-standing financial problem- asset mispricing as a starting point,and proved the possible negative effects news medias have on financial market operations basing on the media effects of the "spiral of silence" theory; Zhang et al. (2016) also used this theory to analyze the contagious influence of two different types of news media ( paper and network ) on inflation expectations. However, because of the demand side motivation, the media often injects emotion to cater to readers' opinions and preferences, which may further influence readers' behavior (e.g., Kindleberger, 1978; Galbraith, 1990; Shiller, 2005) . This phenomenon is called media slant.

With regard to the study of media bias, theoretical and empirical foundations exist in the reader's political preferences to support such arguments. DellaVigna et al. (2007) and Gerber et al. (2009) demonstrated empirical evidence that political news media bias can change public opinion and voting behavior. Mullainathan et al. (2005) and Gentzkow et al. (2006) suggests that people give more credit to information consistent with that have previously been acknowledged by themselves, therefore making the inconsistent one ineffective. Gentzkow et al. (2010) validated this discovery through empirical methods. Tetlock (2007) used the column news of the Wall Street Journal as samples and found that pessimistic media influence constituted a strong downward pressure on stock prices.

\subsection{Emotions and Asset Prices}

Traditional economic theory holds that market entities can always rationally and correctly consider all relevant information obtained in order to achieve maximum utility. However, in the late 1980s, more and more empirical studies pointed out that capital markets are not effective markets, and asset prices can actually be predicted through some relevant information. Genesove et al. (2001) explained the relationship between house price dynamics and consumer expectations through loss aversion effects and seller behavior. Baker et al. (2003) used stock returns that will have been achieved in three years as a proxy variable for investor sentiment. The study found that the higher the stock returns in the future(which means the stock price is now relatively undervalued), the more pessimistic the investor's sentiment, and the lower the level of investment of the company. Edmans et al. (2006) discovered that speculative emotions caused by sporting events drive up the demand for stocks, and speculators tend to buy stocks that are more difficult to arbitrage and thus have a cross-cutting effect on stock prices. Baker et al. (2007) pointed out that it is unquestionable that investor sentiment affect stock prices, the main point is how to measure investor sentiment and quantify its effects. Since then, umpteen empirical studies based on investor sentiment have emerged.

\subsection{Media Influence and Real Estate Prices}

Soo (2013) applied the method of constructing emotional indicators through the news media to the housing market, and examined the role of emotions in the process of large fluctuations in housing prices during the 2008 financial crisis. The emotional indicators constructed can predict price fluctuations within 2 years, and possess explanatory power of more than $70 \%$ for changes in national price. In order to explore the internal mechanism between media reports and house price fluctuations, Zhao (2018) used quarterly data from 21 large and medium-sized cities in China and introduced media attitude with the bridge of expectation into the real estate 
market equilibrium to empirically test the model. Soo (2013) and Zhao (2018) provided new ideas for constructing emotional indicators and explaining the real estate prices. Zhou (2018) find that housing market returns increase with contemporaneous sentiment, and high sentiment is followed by low returns.

\subsection{Macroeconomic Factors Affecting Housing Prices}

The fundamentals are the basic situation of the macro economy, reflecting the macroeconomic operating situation.

\subsubsection{Population}

Chung et al. (2002) In the study, residents' housing consumption was affected by a large number of random events and demographic variables. Mankiw (1991) impacted by analyzing demographic factors which will affect the demand in the housing market and in turn change the house prices and investment behaviour, and explained the how the baby boomers drove up the housing prices in the 1970s when they came of age; and how low population growth in the 1970s led to slow growth in house prices in the 1990s .

\subsubsection{Income}

Leung (2001) contends that the housing consumption function is considered to be relatively stable, mainly depending on the long-term income of consumers. Ortalo-Magné et al. (2002)states in his research that when buying a house as a consumer behavior, the consumption of home purchases is mainly affected by the income of the buyers. Gao et al. (2013) mentioned that while housing prices have risen sharply since 2003, the per capita disposable income of urban residents has increased rapidly. Kuang et al. (2010) found in the study that the impact of income on housing prices is greater than the cost of developers. In other words, housing prices are driven by income.

\subsubsection{Rent}

In addition to the attributes of ordinary commodities, houses can also participate as a financial asset in the basket of investors. Rent is the reward for housing investment, and the level of housing investment will have a substantial impact on the demand for housing purchases.Zhang et al. (2013) found that the news of rent growth contributed the most to the fluctuations in housing market returns.

\subsubsection{Interest Rate}

Bank deposit and loan benchmark interest rate. The regulation of interest rates on real estate is achieved by affecting both supply and demand. By adjusting the interest rate level, the money supply in the market will be changed, then the supply-demand and credit relationship in the real estate market will respond, and ultimately the real estate market price will fluctuate. Stein (1995), Lamont et al. (1999) suggest that the availability of credit can stimulate housing demand, especially in cities where most homeowners are highly leveraged, and house price movements are more sensitive. Shen et al. (2011) found that the impact of interest rates on house prices is significant, interest rates and house prices are negatively related, and there is no mystery of house prices.

\subsubsection{Supply}

When analyzing the housing market, the impact of supply-side changes caused by policies, costs and other factors on the housing market cannot be ignored. Paciorek (2013) constructs a dynamic model structure of housing supply to explore the mechanism by which regulation affects supply and leads to changes in housing prices. Liu et al. (2003) believed that in the real estate development process, developers always form land prices first, and then generate housing construction costs. The cost then passed the supply and demand relationship of the market at that time, and finally formed the transaction price of the house. Therefore, from a supply perspective, rising land prices are a factor contributing to the rise in housing prices. In short, external shocks in all aspects have changed the supply of the housing market and ultimately affected the price and volume of the housing market. The change in the supply status of the real estate market is reflected in the changes in real estate development residential investment, residential saleable data (available sets, saleable area), and new construction area of commercial housing.

\section{Analysis of the Current Situation of Real Estate Market and Home Buyers' Sentiment}

The 2011-2016 China Real Estate Prosperity Index and the Guangzhou Housing Price Base Index (2010=100) data are obtained from the official website of the National Bureau of Statistics of the People's Republic (Note 1), and the 2011-2016 Home Buyer Confidence Index are extracted from the official website of the World Union (Note 2).

The National Housing Climate Index can demonstrate the basic operating conditions of the national real estate 
industry as well as its fluctuations, and forecast future trends from the perspectives of land, capital, development volume, and market demand. According to Figure 1 (Note 3), China's real estate industry is in the depression phase throughout the whole cycle. According to Figure 2, Guangzhou's housing prices generally show a trend of rising volatility. Combined with Figure 1 and Figure 2, Guangzhou's housing prices are highly correlated with the real estate industry. In the declining range of the national housing climate index, such as the second quarter of 2011 to the first half of 2012, Guangzhou housing prices there exhibited a corresponding decline. In the range where the national housing boom index has risen, such as the second half of 2015, the housing prices in Guangzhou have risen accordingly.

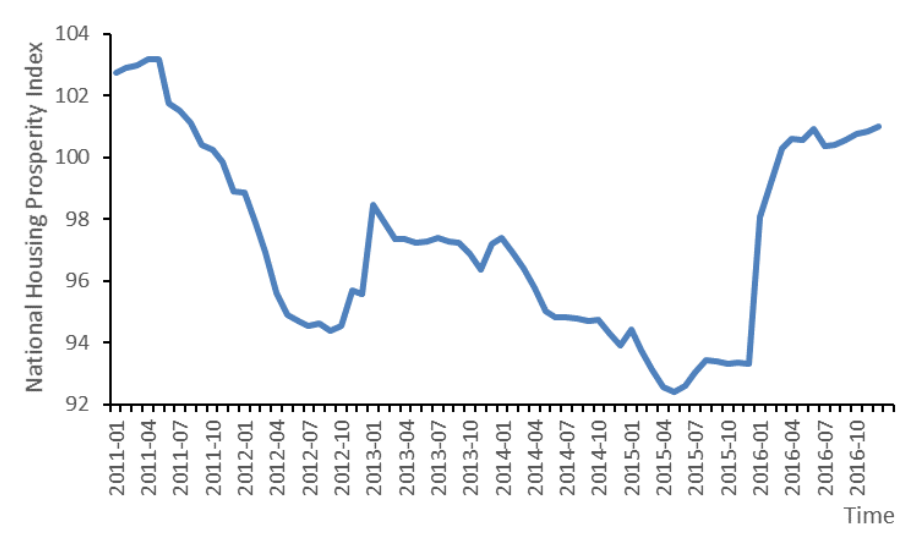

Figure 1. National housing prosperity index 2011.01-2016.12

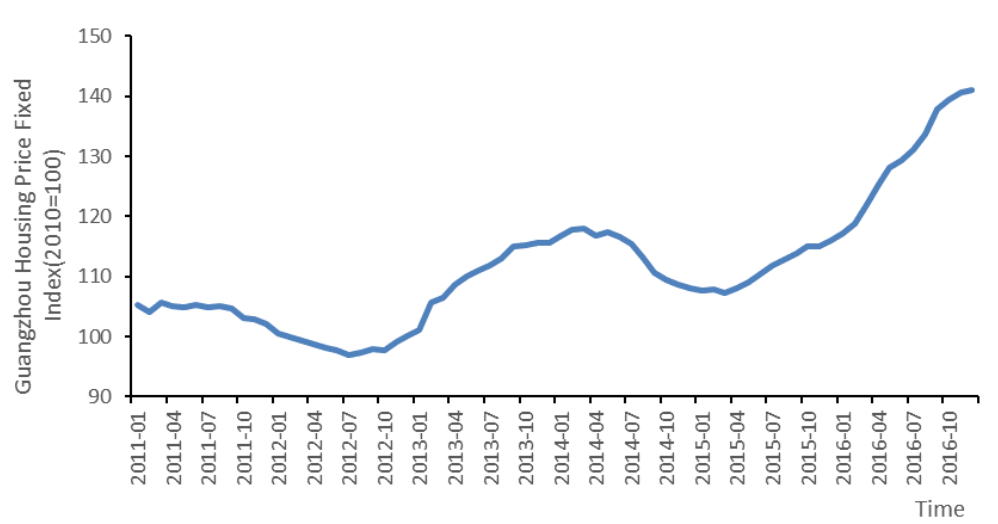

Figure 2. Guangzhou housing price fixed index (2010=100), 2011.01-2016.12

The World Union Buyers' Confidence Index is a leading indicator of the volume trend formed by examining the buyers' evaluation of the living environment, current housing prices, future housing prices, and timing of buying houses. This indicator reflects the current market confidence and is also predicting future housing price trends and markets. According to Figure 3 (Note 4), the Home Buyer Confidence Index only indicated loss of confidence in the fourth quarter of 2016, which tells us that buyers have almost always maintained a positive attitude towards the real estate market. Combined with Figure 1 and Figure 2, the buyers' confidence index and the national housing prosperity index, which can be used as substitutes for the mental expectations of buyers, are highly correlated with the Guangzhou housing price-based index, which indicates the sentiment of buyers and the real estate market :when the home buyers' confidence index is on the rise, the real estate market is gradually improving, and house prices are also on the rise, and vice versa. Exploring the relationship between buyers' sentiment and house prices is a topic worth studying. 


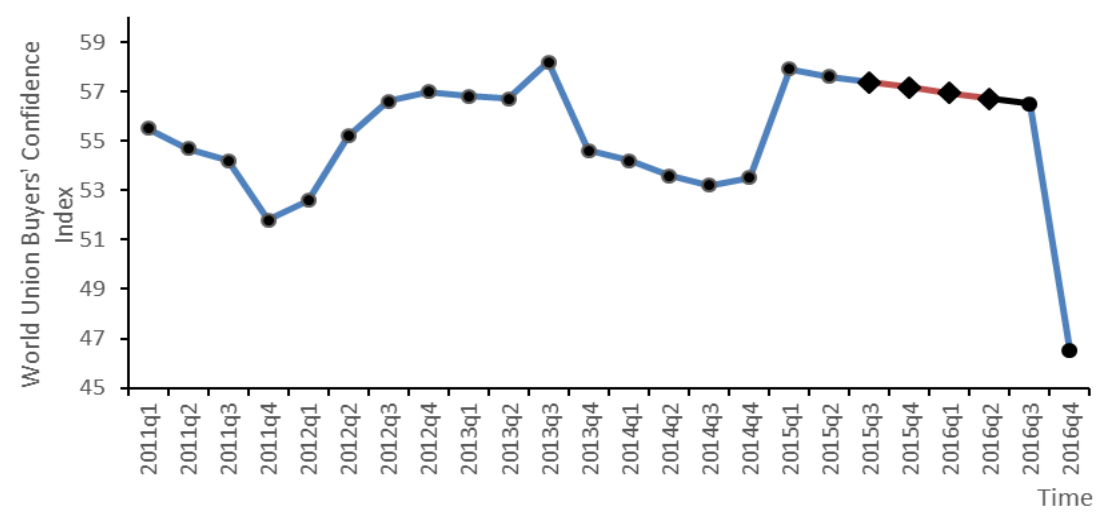

Figure 3. World union buyers' confidence index: 2011-2016

\section{The Construction of the Buyer Confidence Index}

This paper uses the media text mining method used by Soo (2013) to construct a substitute variable for the buyer's mental expectations - the buyer confidence index. The detailed construction process and specific methods are as follows:

\subsection{Building an Article Pool}

Soo (2013) believes that it is completely reasonable to choose newspaper as the source of article. On the one hand, newspaper, as a traditional media, is still the main way for home buyers to obtain information. On the other hand, the information published by the media on its website often appears in newspapers. Therefore, this article will use newspapers as a source of media text.

\subsubsection{Sampling of Newspapers}

This article selects the most influential newspapers in the region as the source of the article. To this end, major newspapers chosen based on the "2016 China Media Convergence spread index report" released by the People's Institute in December 19, 2016 (Note 5). In the report, a newspaper and magazine fusion communication index system were established to evaluate the content, number of users and influence of newspapers and periodicals in various channels. Based on the report, the local medias that entered the list of top 100 newspaper includes Guangzhou Daily, Yangcheng Evening News, the Nanfang Daily, Southern Metropolis Daily, News Express, their rankings are reported in Table 1:

Table 1. Guangzhou newspaper of the 2016 China newspaper media top 100

\begin{tabular}{ccc}
\hline Newspaper name & National comprehensive ranking & overall ratings \\
\hline Guangzhou Daily & 4 & 85.89 \\
Yangcheng Evening News & 5 & 84.74 \\
Southern Daily & 7 & 83.96 \\
Southern Metropolis Daily & 8 & 83.73 \\
News Express & 25 & 73.98 \\
\hline
\end{tabular}

\subsubsection{Sampling of the Article}

After selecting the mainstream newspapers in each city, this article searches the Wisers News Search Research Database (Note 6). for articles about the housing market in mainstream newspapers in Guangzhou. This article uses Python to design an automated search and download program to complete the retrieval and download of all eligible articles by specifying dates, media, keywords from this platform. This article finally obtained a total of 115,139 articles on the housing market, forming an article pool for text mining.

\subsection{Constructing Emotional and Emotional Indexes}

\subsubsection{Determine the Emotional Polarity of the Vocabulary}

In quantifying media influence, text analysis of sample articles in the article pool is required. At present, the common method of academic research is to judge the polarity of media influence by counting the frequency of 
positive vocabulary and negative vocabulary. Therefore, it is important to set accurate and appropriate bar for the judgment of positive vocabularies and negative vocabularies. Due to the differences between different languages, this paper gives priority to the Chinese vocabulary list. Relevant research in China mostly uses the Chinese positive vocabulary and negative vocabulary provided by the CKNI Emotional Polarity Dictionary and Taiwan University Chinese General Emotion Dictionary. However, the above two dictionaries are differently cited by CSSCI and CSCD's top 30 journals. The CKNI Emotional Polarity Dictionary was cited once, and the Taiwan University Chinese General Emotion Dictionary was cited 8 times. Therefore, this paper distinguishes the polarity of Chinese vocabularies basing on the Taiwan University Chinese General Emotion Dictionary.

\subsubsection{Calculation of Sentimental Indicators}

This article defines the sentimental indicators of the news media during the t period $\left(\mathrm{S}_{\mathrm{t}}\right)$ :

$$
S_{t}=(p o s-n e g) /(p o s+n e g)
$$

among which pos Indicates the number of positive vocabulary contained in newspaper articles during the $t$ period, neg Indicates the number of negative vocabulary contained in newspaper articles during the $t$ period. The range of values of $S_{t}$ is $[-1,1]$. When the sentimental index takes negative value, it shows that the negative vocabulary in the newspaper articles in the t period is more than the positive vocabulary, and the media influences are negative; the higher the absolute value, the intender the negative media influence. When the sentimental index takes value 0 , it shows that the negative vocabulary in the newspaper articles of the $t$ period is equal to the positive vocabulary, and the media influence is neutral. When the sentimental index takes positive value, it shows that the positive vocabulary in the newspaper articles in the t period is more than the negative vocabulary, the larger the value, the more positive vocabularies, and the higher the positiveness of the media influence.

\subsubsection{Calculation of the Sentiment Index}

This paper adopts Soo (2013) 's sentiment index construction method to perform a 12-period moving average on the sentimental index and interpolate the missing values. We construct the Sentiment Index ( sentiment $\left.t_{t}\right)$ as follows :

$$
\text { sentiment }_{i t}=\left(s_{t}+s_{t-1}+\ldots+s_{t-11}\right) / 12
$$

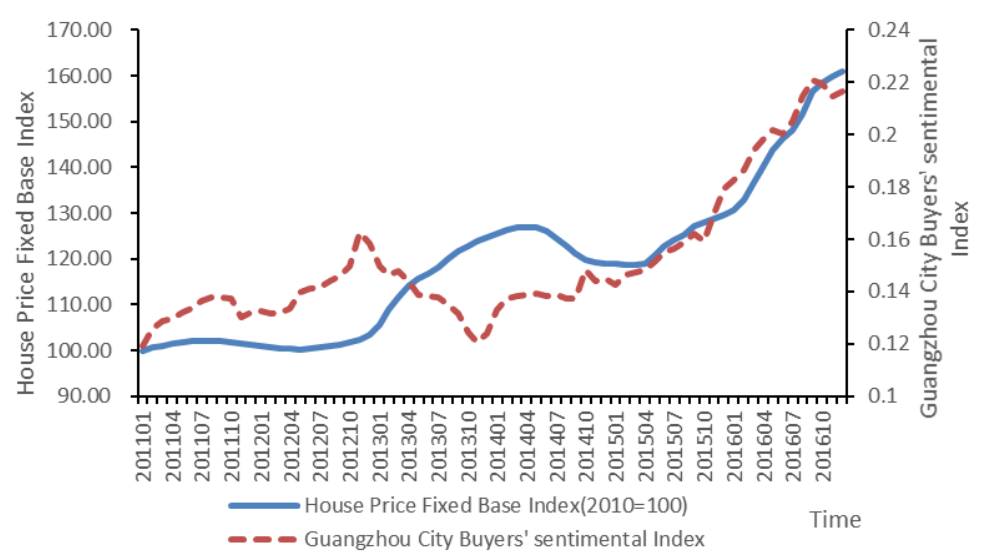

Figure 4. Comparison of Guangzhou city buyers' sentimental index and house price fixed base index $(2010=100)$ : 2011-2016

\subsection{Description of the Buyer Confidence Index}

This paper draws the sentiment index of Guangzhou buyers, which is compared with the Guangzhou city price base index $(2010=100)$ as shown in Figure 4. According to Figure 4, the Guangzhou City Buyers' sentimental Index has a strong correlation with the Guangzhou City Price Fixed Base Index $(2010=100)$ and has a leading edge: beginning in January 2011, the surging buyers sentiment led to a rise in house prices in about two years later; conversely, the waning of home buyers' sentiment beginning in October 2012 led to the downward trend of house prices two years later. In the next section, this article will use multiple linear regression to explain housing prices. 


\section{The Relationship between Home Buyers' Sentiment Index and House Prices}

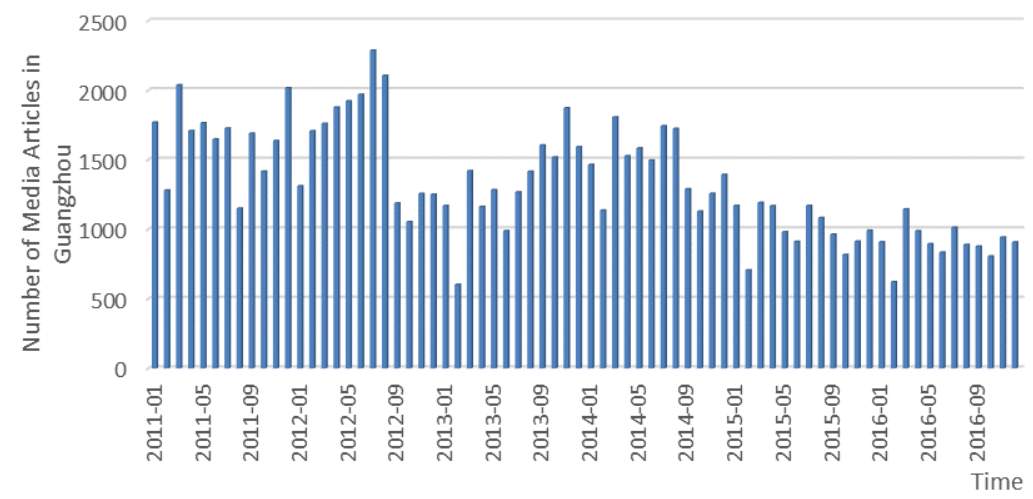

Figure 5. Distribution of the number of media articles in Guangzhou: 2011-2016

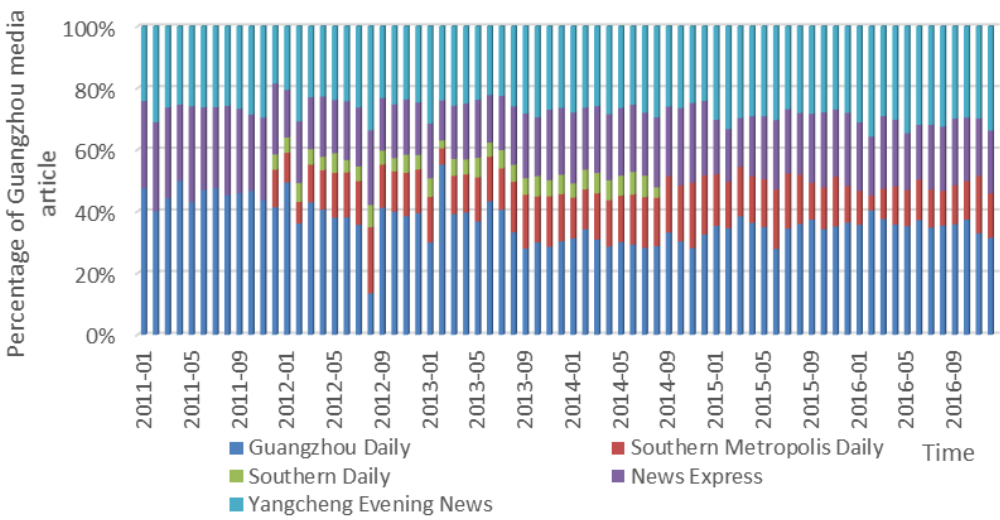

Figure 6. Structure of Guangzhou media article: 2011-2016 (unit: \%)

\subsection{Samples and Data}

This paper selects the economic variables that affect housing prices based on the two aspects of supply and demand. Since the monthly data of factors such as income, population are not available, these indicators are excluded from this article. On this basis, the factors selected that affect the housing supply are: actual residential development investment, completed area, and new construction area; and the factors affecting consumers' demand for housing are: actual loan benchmark interest rate, sales area, investment capital Ratio and buyer's mental expectations of housing prices.

Due to the poor integrity and continuity of media articles before 2011 in the Huike News Media Search Database, we use samples from 2011 to 2016 as the source of media articles to build a home buyer sentiment index. Figure 5 shows the distribution of the number of media articles in Guangzhou, and Figure 6 shows the structure of the source of media articles in Guangzhou. As can be seen, there are more than 500 articles each month in the article pool .Although the structure of the samples in the article pool is not exactly the same every month, this will not affect the measure of the buyer confidence. The rest of the data used in multiple linear regression analysis are derived from the National Bureau of Statistics of the People's Republic of China.

\subsection{Models and Variables}

Drawing on the multiple linear regression models of Soo (2013) and Zhao (2018) on the impact of buyers' sentiment on housing prices, this paper establishes the following measurement models:

$$
\begin{gathered}
\ln \left(\text { price }_{t}\right)=\alpha+\beta_{1}\left(\text { sentiment }_{t}\right)+\beta_{2} \ln \left(\text { investmen }_{t}\right)+\beta_{3} \ln \left(\text { completion }_{t}\right)+\beta_{4} \ln \left(\text { new }_{t}\right)+\beta_{5} \ln \left(1+\text { interest }_{t}\right)+ \\
\beta_{6} \ln \left(\text { sale }_{t}\right)+\beta_{7} \ln \left(\text { ic }_{t}\right)+\varepsilon_{t}
\end{gathered}
$$

price $_{\mathrm{t}}$ represents the house price index sentiment represents the sentiment index of the buyers,investment $\mathrm{t}_{\mathrm{t}}$ stands 


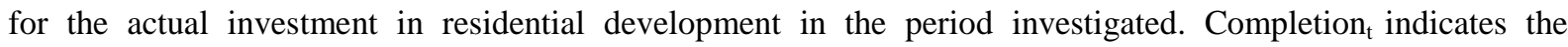
completion area during period $t$, and new $\mathrm{w}_{\mathrm{t}}$ represents the new construction area of $\mathrm{t}$ period, while interest $\mathrm{t}_{\mathrm{t}}$ stands for the actual loan benchmark interest rate for period t. Sale ${ }_{t}$ Indicates the sales area during the period, and $i_{t}$ indicates the investment capital ratio of the t period. The $\ln \left(\mathrm{X}_{\mathrm{t}}\right)$ in formula (3) represents the logarithm of sequence $X_{t}$. Since some macroeconomic variables, such as population and income, are not monthly announced on official sources, they are temporarily omitted in the model.

\subsection{Descriptive Statistics}

Table 2. Descriptive statistics of each variable

\begin{tabular}{ccccccc}
\hline & Obs & Mean & Std. Dev. & Min & Median & Max \\
\hline Price & 72 & 119.0084 & 16.6133 & 100.0000 & 119.1410 & 161.0855 \\
Sentiment & 72 & 0.1519 & 0.0264 & 0.1190 & 0.1421 & 0.2206 \\
Investment & 72 & 81.9248 & 38.6212 & 9.7800 & 78.1250 & 198.3200 \\
Completion & 72 & 74.4775 & 141.4603 & 0.0500 & 24.8450 & 790.9100 \\
New & 72 & 105.1656 & 63.3282 & 14.5800 & 96.1250 & 265.6500 \\
Interest & 72 & 0.2707 & 0.4923 & -0.9700 & 0.3325 & 1.4300 \\
Sale & 72 & 107.2138 & 46.9221 & 22.5200 & 111.0000 & 224.2400 \\
Ic & 72 & 0.0193 & 0.0088 & 0.0020 & 0.0189 & 0.0438 \\
\hline
\end{tabular}

According to Table 2, the statistical characteristics of the Guangzhou City House Price Index Sequence and the Guangzhou City Buyers' sentimental Index Sequence are similar. Figure 4 shows that Guangzhou City Buyers' Mental expectations and Guangzhou City House Prices enjoyed a boom at the end of 2013 and the end of 2015 respectively, resulting in the difference between the maximum value and the mean of the sequence being much larger than the difference between the mean and the minimum. As shown in Figure 7, the standard deviations of the completed area, new construction area and sales area are large, which is closely related to seasonality. That the area of completion peaked in December was due to the industry habits of the real estate industry. The sales area usually touched the bottom during the Chinese New Year in February, while the new construction area and other economic variables were relatively stable throughout the year.

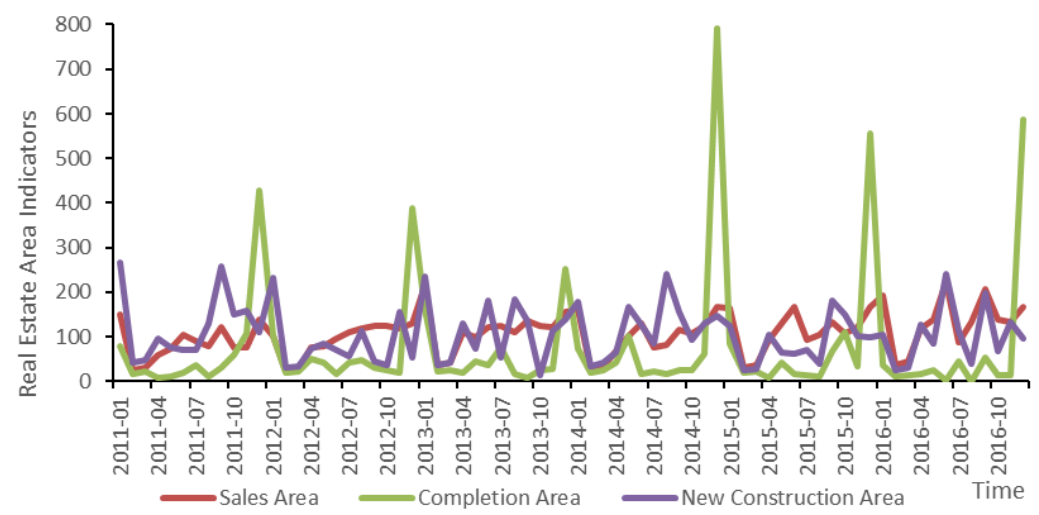

Figure 7. Comparison of real estate area indicators in Guangzhou: 2011-2016 (unit: 10,000 square meters)

\subsection{Unit Root and Cointegration Test}

In order to avoid pseudo-regression, the unit root and cointegration test will be carried out in this paper. The test results are shown in Table 3 and Table 4. The unit root test results show that there is a unit root phenomenon in Guangzhou's house price base index and Guangzhou city buyers' sentiment index. The cointegration test results show that there is a first-order relationship between Guangzhou's house price base index and Guangzhou city buyers' sentiment index. Therefore we can directly perform linear regression analysis. 
Table 3. Dicky-Fuller unit root test results

\begin{tabular}{ccc}
\hline & $\mathrm{t}$ statistic & P-value \\
\hline Price & 4.127 & 1 \\
Sentiment & 1.03 & 0.9946 \\
\hline
\end{tabular}

Table 4. Johansen cointegration test

\begin{tabular}{cccccc}
\hline Maximum rank & Parms & LL & Eigenvalue & Trace statistic & $5 \%$ critical value \\
\hline 0 & 2 & 167.9394 &. & 38.4953 & 15.41 \\
1 & 5 & 187.0382 & 0.41608 & $0.2976^{*}$ & 3.76 \\
2 & 6 & 187.187 & 0.00418 &. &. \\
\hline
\end{tabular}

\section{5 multiple Linear Regression}

According to the econometric model of equation (3), multiple linear regression was used to analyze after passing the cointegration test. The results are shown in Table 4 below .

Table 5. Model regression results

\begin{tabular}{|c|c|}
\hline variables & coefficient \\
\hline \multirow[t]{2}{*}{$\ln \left(\right.$ sentiment $\left._{\mathrm{t}}\right)$} & $0.6350 * * *$ \\
\hline & $(0.0856)$ \\
\hline \multirow[t]{2}{*}{$\ln \left(1+\right.$ interest $\left._{\mathrm{t}}\right)$} & 0.0003 \\
\hline & $(0.0162)$ \\
\hline \multirow[t]{2}{*}{$\ln \left(\right.$ sale $\left._{t}\right)$} & -0.0202 \\
\hline & $(0.0323)$ \\
\hline \multirow[t]{2}{*}{$\ln \left(\right.$ investment $_{\mathrm{t}}$ ) } & $-0.7181 * * *$ \\
\hline & $(0.1670)$ \\
\hline \multirow[t]{2}{*}{$\ln \left(\right.$ completion $\left._{\mathrm{t}}\right)$} & -0.0054 \\
\hline & $(0.0072)$ \\
\hline \multirow[t]{2}{*}{$\ln \left(\right.$ new $\left._{t}\right)$} & 0.0194 \\
\hline & $(0.0261)$ \\
\hline \multirow[t]{2}{*}{$\ln \left(\mathrm{ic}_{\mathrm{t}}\right)$} & $0.7496^{* * *}$ \\
\hline & $(0.1650)$ \\
\hline
\end{tabular}

The regression results show that in the fundamental variables, the actual residential development investment amount on the supply side has a significantly negative correlation with the house price index, indicating that when the actual residential development investment amount increases by $1 \%$, the house price index will fall by an average of $0.7181 \%$. When the actual residential development investment fell by $1 \%$, the house price index would increase by an average of $0.7181 \%$. On the demand side, the investment capital ratio is positively correlated with the house price, that is, when the investment capital ratio increases by $1 \%$, the house price index will rise by an average of $0.7496 \%$, and when the investment capital ratio drops by $1 \%$, the house price index will drop by an average of $0.7496 \%$.

The buyer confidence index constructed in this paper has a significant positive correlation with the house price index, which is reflected in the fact that when the buyer confidence rises by $1 \%$, the house price index will rise by an average of $0.6350 \%$. When the buyer confidence falls by $1 \%$, the house price index will decrease by $0.6350 \%$ on average. When the mental expectations of buyers are more positive, buyers have more confidence in the real estate market and are willing to acquire real estate at higher prices, thus driving up the price.

\section{Conclusion}

With the development of behavioral economics, this paper recognizes that animal spirits are the key factors driving economic change by grasping the psychology and sentiments of real estate market trading entities to analyze the inherent fluctuations in house prices and trading volume. It is of great significance to understanding and reasonably explain the mechanism the actual operational characteristics of real estate prices.

Taking Guangzhou as an example, this paper uses text mining to construct a buyer confidence index that can 
prove the relationship between buyers' sentiment and house prices. In the sample period of this article, the sentiment of buyers has a significant positive correlation with house prices, that is, the more positive the mood of buyers, the more the house prices will have an upward trend. Therefore, the government can predict and regulate housing prices by analyzing media texts, thereby making the real estate market more effective, and gradually reducing housing prices to a rational level, thus paving solid foundation for healthy economic growth.

\section{References}

Ahern, K. R., \& Sosyura, D. (2015). Rumor has it: Sensationalism in financial media. The Review of Financial Studies, 28(7), 2050-2093. https://doi.org/10.1093/rfs/hhv006

Baker, M., \& Wurgler, J. (2007). Investor sentiment in the stock market. Journal of Economic Perspectives, 21(2), 129-152. https://doi.org/10.1257/jep.21.2.129

Baker, M., Stein, J. C., \& Wurgler, J. (2003). When does the market matter? Stock prices and the investment of equity-dependent firms. The Quarterly Journal of Economics, 118(3), 969-1005. https://doi.org/10.1162/00335530360698478

Chen, Y. (2005). Mood Fluctuation and Asset Price Fluctuation. Financial Research, (03), 36-45. Retrieved from http://kns.cnki.net/kns/detail/detail.aspx?FileName=JJYJ200503003\&DbName=CJFQ2005

Chung, E. C., \& Haurin, D. R. (2002). Housing choices and uncertainty: The impact of stochastic events. Journal of Urban Economics, 52(2), 193-216. https://doi.org/10.1016/S0094-1190(02)00008-6

DellaVigna, S., \& Kaplan, E. (2007). The Fox News effect: Media bias and voting. The Quarterly Journal of Economics, 122(3), 1187-1234. https://doi.org/10.1162/qjec.122.3.1187

Deng, G., Gan, L., \& Wu, Y. (2010). Is there any overreaction in the real estate market. Management World, (06), 41-55. Retrieved from http://kns.cnki.net/kns/detail/detail.aspx?FileName=GLSJ201006005\&DbName= CJFQ2010

Edmans, A., Garcia, D., \& Norli, Ø. (2007). Sports sentiment and stock returns. The Journal of Finance, 62(4), 1967-1998. https://doi.org/10.1111/j.1540-6261.2007.01262.x

Galbraith, J. (1990). A Short History of Financial Euphoria. New York: Viking Press.

Gao, B., Wang, W., \& Li, X. (2013). The mystery of expectation, income gap and scissors difference in China's urban housing rent. Economic Research (6), 100-112. Retrieved from http://kns.cnki.net/kns/detail/detail.aspx?FileName=JJYJ201306010\&DbName=CJFQ2013

Genesove, D., \& Mayer, C. (2001). Loss aversion and seller behavior: Evidence from the housing market. The Quarterly Journal of Economics, 116(4), 1233-1260. https://doi.org/10.1162/003355301753265561

Gentzkow, M., \& Shapiro, J. M. (2006). Media bias and reputation. Journal of political Economy, 114(2), 280-316. https://doi.org/10.1086/499414

Gentzkow, M., \& Shapiro, J. M. (2010). What drives media slant? Evidence from US daily newspapers. Econometrica, 78(1), 35-71. https://doi.org/10.3982/ECTA7195

Gerber, A. S., Karlan, D., \& Bergan, D. (2009). Does the media matter? A field experiment measuring the effect of newspapers on voting behavior and political opinions.American Economic Journal: Applied Economics, 1(2), 35-52. https://doi.org/10.1257/app.1.2.35

Gurun, U. G., \& Butler, A. W. (2012). Don't believe the hype: Local media slant, local advertising, and firm value. The Journal of Finance, 67(2), 561-598. https://doi.org/10.1111/j.1540-6261.2012.01725.x

Himmelberg, C., Mayer, C., \& Sinai, T. (2005). Assessing high house prices: Bubbles, fundamentals and $\begin{array}{lllll}\text { misperceptions. Journal of } & \text { Economic }\end{array}$ https://doi.org/10.1257/089533005775196769

Huang, J., Wang, W., \& Pei, K. (2013). liter behavioral finance research on the mechanism of dynamics of prices is expected to land the role of , Finance and Economics, (07), 134-144. Retrieved from http://dx.chinadoi.cn/10.16538/j.cnki.jfe.2013.07.009

Jiang, H., \& Yan, K. (2011). The Impact of Mental expectations on China's Real Estate Price in the Post-Crisis Era — Taking Chengdu as an Example. Economist, (12), 48-56. Retrieved from http://dx.chinadoi.cn/10.16158/j.cnki.51-1312/f.2011.12.004

Kindelberger, C. P., \& Manias, P. (1978). Crashes: A History of Financial Crises. New York: Basic Book. 
Kuang, W. (2010). The impact of interest rates on housing prices. World Economy, (4), 134-145. Retrieved from http://kns.cnki.net/kns/detail/detail.aspx?FileName=SJJJ201004011\&DbName=CJFQ2010

Lamont, O., \& Stein, J. C. (1999). Leverage and house-price dynamics in us cities. Rand Journal of Economics, 30(3), 498-514. https://doi.org/10.2139/ssrn.147910

Leung, C. K. Y. (2001). Relating international trade to the housing market. Review of Development Economics, 5(2), 328-335. https://doi.org/10.1111/1467-9361.00126

Li, R. Y. M., \& Li, H. C. Y. (2018). Have Housing Prices Gone with the Smelly Wind? Big Data Analysis on Landfill in Hong Kong. Sustainability, 10(2), 341. https://doi.org/10.3390/su10020341

Li, R. Y. M., \& Wong, J. F. K. (2016). Market Sentiment and Property Prices in Hong Kong. Econometric Analyses of International Housing Markets, Routledge.

Lin, S., \& Yu, Q. (2010). Bounded Rationality, Animal Spirit and Market Collapse: An Experimental Study of Emotional Fluctuation and Trading Behavior. Economic Research, (08), 115-127. Retrieved from http://kns.cnki.net/kns/detail/detail.aspx?FileName=JJYJ201008009\&DbName=CJFQ2010

Liu, L., \& Liu, H. (2003). Economic analysis of the relationship between land price and house price. Quantitative Economics and Technology Economics Research, (7), 27-30. http://dx.chinadoi.cn/10.13653/j.cnki.jqte.2003.07.005

Mankiw, N. G., \& Weil, D. N. (1991). The baby boom, the baby bust, and the housing market. Reg Sci Urban Econ, 19(2), 235-258. https://doi.org/10.1016/0166-0462(89)90005-7

Mullainathan, S., \& Shleifer, A. (2005). The market for news. American Economic Review, 95(4), 1031-1053. https://doi.org/10.1257/0002828054825619

Ortalo-Magné, F., \& Rady, S. (2002). Homeownership: Low household mobility, volatile housing prices, high income dispersion. Cesifo Working Paper, 12(9), 254-262.

Paciorek, A. (2013). Supply constraints and housing market dynamics. Journal of Urban Economics, 77(1), 11-26. https://doi.org/10.1016/j.jue.2013.04.001

Shen, Y., Zhou, K., \& Li, S. (2011). Analysis of the Effectiveness of Interest Rate on House Price — Based on Favar Model. Economic Science, 33(1), 60-69. http ://dx.chinadoi.cn/10.19523/j.jjkx.2011.01.007

Shiller, R. J. (2005). Irrational exuberance. Princeton university press.

Soo, C. K. (2013). Quantifying animal spirits: news media and sentiment in the housing market. Social Science Electronic Publishing. https://doi.org/10.2139/ssrn.2330392

Stein, J. C. (1995). Prices and trading volume in the housing market: A model with down-payment effects. Quarterly Journal of Economics, 110(2), 379-406. https://doi.org/10.2307/2118444

Tetlock, P. C. (2007). Giving content to investor sentiment: The role of media in the stock market. The Journal of Finance, 62(3), 1139-1168. https://doi.org/10.1111/j.1540-6261.2007.01232.x

Wang, C., \& Wu, J. (2015). Media tone, investor sentiment and IPO pricing. Financial Research, (09), 174-189. Retrieved from http://kns.cnki.net/kns/detail/detail.aspx?FileName=JRYJ201509012\&DbName=CJFQ2015

Wang, J., \& Gao, T. (2004). Dynamic Analysis of Demand and Supply Function of China's Real Estate Market. China Soft Science, (4), 69-74. Retrieved from http://kns.cnki.net/kns/detail/detail.aspx?FileName= ZGRK200404013\&DbName=CJFQ2004

You, J., \& Wu, J. (2012). Silent Spiral: Media Emotion and Asset Mispricing. Economic Research, (07), 141-152. Retrieved from http://kns.cnki.net/kns/detail/detail.aspx?FileName=JJYJ201207012\&DbName =CJFQ2012

Zhang, C., \& Lu, Z. (2016). Asymmetric spiral : media influence and inflation expectations contagion. Finance and Trade, (06), 51-66. Retrieved from http://kns.cnki.net/kns/detail/detail.aspx?FileName= CMJJ201606005\&DbName $=$ CJFQ2016

Zhang, H. (2012). Preliminary Study on the Formation Mechanism and Quantitative Analysis of House Price. China Real Estate: Academic Edition, (8), 14-19. Retrieved from http://dx.chinadoi.cn/10.16538/j.cnki.jfe.2016.08.005

Zhang, H. (2016). Heterogeneity Expectation, Investor Behavior and House Price Fluctuation: A Tale of Two Cities in Shanghai and Guangzhou. Finance and Economics Research, (08), 51-61+120. Retrieved from http://dx.chinadoi.cn/10.13562/j.china.real.estate.2012.16.003 
Zhang, H., Li, Y., \& Yang, F. (2013). Based on the dynamic Gordon model, the cause of income fluctuations in China's housing market. Journal of Tongji University, 41(11), 1755-1760. Retrieved from http://kns.cnki.net/kns/detail/detail.aspx?FileName=TJDZ201311025\&DbName=CJFQ2013

Zhang, Z., \& Zhu, W. (2010). Inflation hallucinations, expected deviations and stock market valuations. Financial Research, (05), 116-132. Retrieved from http://kns.cnki.net/kns/detail/detail.aspx?FileName= JRYJ201005011\&DbName=CJFQ2010

Zhao, X., \& Tu, M. (2008). Have studied the real estate market transactions. Finance and Economics, (01), 136-143. http://dx.chinadoi.cn/10.16538/j.cnki.jfe.2008.01.012

Zhou, J. (2015). Belief, Feedback Effect and Game Equilibrium: A Game Theory Interpretation of Real Estate Speculation Bubble Formation. World Economy, (05), 21-27+80. Retrieved from http://kns.cnki.net/kns/detail/detail.aspx?FileName=SJJJ200505004\&DbName=CJFQ2005

Zhou, Z. (2018) Housing Market Sentiment and Intervention Effectiveness: Evidence from China. Emerging Markets Review. https://doi.org/10.1016/j.ememar.2017.12.005

\section{Notes}

Note 1. The official website of the National Bureau of Statistics: http://www.stats.gov.cn/

Note 2. The official website of the World Union: http://www.worldunion.com.cn/

Note 3. According to the rules of the national housing prosperity index of People's Republic of China National Bureau of statistics, the national housing boom index is 100 as the critical value, the index value is higher than 100 is the boom space, and less than 100 is the recession space.

Note 4. In the third quarter of 2015 to the second quarter of 2016, the World Federation suspended the release of the confidence index for the buyers. This article uses interpolation to fill the missing data. According to World Federation's confidence index of home buyecors, the buyer's confidence index has a critical value of 50, when the index is higher than 50, buyers have confidence in the real estate market, and when it's less than 50, we say buyers have lost confidence in the real estate market.

Note 5. Source:media.people.com.cn/n1/2016/1219/c120837-28960709.html

Note 6. The official website of Wisers database:https://www.wisers.com/

\section{Copyrights}

Copyright for this article is retained by the author(s), with first publication rights granted to the journal.

This is an open-access article distributed under the terms and conditions of the Creative Commons Attribution license (http://creativecommons.org/licenses/by/4.0/). 